\title{
STRENGTHEN THE INDONESIAN ECONOMIC SOCIETY THROUGH SPORT TOURISM
}

\author{
Titin Kuntum Mandalawati, Universitas PGRI Madiun \\ Ardyansyah Arief Budi Utomo, Universitas PGRI Madiun \\ Hagus Muryanto, Universitas PGRI Madiun \\ Email: mandalawatititin@gmail.com
}

\begin{abstract}
To face the challenges of the global economy especially in the field of sports, Indonesia has a good chance. Every region of Indonesia has a great beauty, but the people of Indonesia have not been able to utilize, manage and preserve properly. Sport Tourism is one of the strategies that is quite effective in improving the tourism industry in Indonesia. Therefore, the need for cooperation between the society, local government and the Ministry of Tourism to be able to develop and provide excellent tourist destinations. One of the policy breakthroughs that can be done is to combine tourism and sports culture. In addition to additional income, it is expected that the people and the government of Indonesia are able to manage well, preserve the natural surroundings, able to cultivate the community and promote sports.
\end{abstract}

Keywords: Economy Society, Sport Tourism

Facing the challenges of the global economy, especially in the field of sports, Indonesia has a good chance. Every corner of Indonesia has a great beauty, from Sabang to Merauke. Indonesia is also called the archipelago because there are so many islands more or less there are 17,505 islands. Unfortunately, the people of Indonesia can not utilize, manage and preserve them maximally. In today's era of globalization, present time the tourism sector has become one of the largest and strongest industries in the world, and tourism is the largest contributor to the supply of income, especially in the economy of society and the state. So, the role of tourism in the economic development of a society or of a country is very large.

According to Susilo Bambang Yudoyono "There are three conditions facing global challenges; strengthen the nation's independence, increase competitiveness, and have a noble civilization nation ". Through the tourism sector Indonesia can strengthen the independence of the nation and improve the competitiveness, especially in the economy of Indonesian society. In Tourism Law No. 09 of 1990 stating "Tourism is an important role to broaden and declare business opportunities and employment, encourage regional development, increase national income in order to improve the welfare and prosperity of the people and foster the love of the homeland, enrich the national culture and strengthen its development in order to strengthen national identity and strengthen friendship among nations ". Cultural tourism as a policy of Indonesian tourism development emphasizes on the appearance of cultural elements as the main asset attracts tourists to visit Indonesia. Not only will culture be better with a touch of sports tourism. Combining sporting tourism and displaying local cultural wisdom is expected to bring many benefits to the people's economy. Therefore, the need for cooperation between the community, local government and the Ministry of Tourism will be able to develop and provide excellent tourist destinations in their respective regions. 


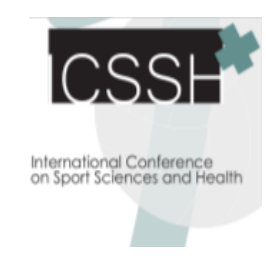

\section{DISCUSSION}

\section{Indonesia Economic Community}

The economy (Perekonomian) has the basic word economy (ekonomi) comes from the word oikos and nomos. Oikos is the household and nomos means set up. From the base of the word the economy(ekonomi) gets affixed per and an, so it becomes an word economy (perekonomian) that has a sense of action, rules or procedures on managing the household economy and goals to meet the needs of life. So the economy of Indonesian society is the way or effort done by the people of Indonesia in regulating the economy to be better for all the people of Indonesia. It is for the welfare of the community economy management of economic development not only refers to the government, but also requires the participation of intellectuals, business people and society. Indonesia is a country rich in natural resources and culture, but the management of natural resources has not been able to prosper the people of Indonesia.

The condition of the Indonesian economy is still alarming with the poverty rate reaching 28.59 million people or $11.22 \%$ of the total population of Indonesia. This causes a social gap between the rich and the poor, but also the low purchasing power. Indonesia's current economic condition can be said to be far from expectations. Indonesia's economy is slow because of the problems faced today. One of the problems that we often see is the social gap between upper middle class and lower society which happens because of the inequality caused by the slow growth of the country's current economy. It can be said that " in assessing the Indonesian economy we can see from the condition of people's homes " (Wicaksono, 2013). The conclusion is people who have a good home is rich and they with bad house means people who are not rich (the gap of Indonesian economy), the number of unemployment is also the problem of the Indonesian economy today.

According to Wicaksono (2013) Problems affecting the Indonesian economy today comprise a wide range of areas, such as problems arising in the areas of household, food, services, deflation and inflation as well as government non-discretion in prioritizing the needs of the general public. In this case the need for cooperation between government and society. Especially economic actors are the entire Indonesian community to think creatively and innovatively to build the economy and government facilitate without any complicated bureaucracy. Efforts to improve the economic problems when pressing the poverty rate by providing capital to the people to be able to try independently, such as giving farmers and fishermen credits, small business loans for small and medium entrepreneurs, increasing investment both from within and outside the country to create field so that the government can provide essential goods in large quantities and sufficient so that there is no shortage of basic needs. In addition there needs to be subsidized so that the price of basic necessities do not rise and can be reached by the community.

In the face of global economy so far Indonesia has proved as one of the countries that have resilience in facing global economic crisis. It can not be denied, tourism until now is still an industry that can move the economy quickly and efficiently. Various tourism variants continue to be developed to make this sector as one of the mainstays in the regional and national economies. The tourism sector is a major contributor to Gross Domestic Product (GDP) and foreign exchange. It was realized the Ministry of Tourism (Kemenpar), who intend to maximize the potential of Indonesia's tourism. According to Deputy of Institutional Development of Tourism Kemenpar Ahman Sya, tourism is also able to create jobs easily. The contribution of tourism foreign exchange to national foreign exchange earnings in 2015 reached US $\$ 12.6$ billion or 9.3 percent. The number is ranked fourth after the oil and gas, coal and palm oil sectors (national daily, 2017)

Sport tourism, in recent years is increasingly widespread, seeing from some countries for example Europe has promoted sport tourism as one of tourism product 
diversification. Almost all parts of the world of Sports Tourism is now increasingly advanced so that many areas of sport are now used as objects and attractions for tourists, especially sports that take advantage of natural facilities such as mountains, lakes, rivers, seas and only offers the charm of natural beauty.

A number of positive effect have been born from sports attractions and are expected to continue to roll into snowballs to support the development of the land. According to Lakoni cited by Fandeli (1995) Tourism is a very strategic sector to improve the income of the state and society. The ongoing development of the tourism sector will continue to lift other sectors of the economy.

\section{Sport Tourism}

Travel is a journey activity undertaken by a person or group of persons by visiting a particular place for recreational purposes, personal development, or studying the unique attractions of the visited tourist in temporary period.Sport is not just talking about the context of achievement alone, but more broadly that is in the context of recreation (Law Number 10 Year 2009: 2).In the Law of the Republic of Indonesia No 3 of 2005 on the national sports system, it is also mentioned that sports recreation is a sport conducted by the community with a passion and ability to grow and develop in accordance with the conditions and cultural values of local communities for health, fitness and pleasure (Article 1 verse 12). In this case, sport and tourism have the same goals. If the sport aims to provide pleasure then tourism is an activity that is done to get pleasure.

In this case, the Local Government and the Department of Tourism should cooperate in realizing sports tourism to increase local revenue. In addition, local communities should also be involved in order for the local economy to improve as well.Sports tourism can be a nature tour that is managed and developed or it could also be artificial tours that are modified with a specific shape and purpose.Of course with the development of sport tourism, it is expected to attract the attractiveness of domestic and foreign tourists who will impact on local revenue in local government. Sport Tourism by Spillane (1987: 30) is divided into 2 categories:

1. Big Sport Event

They are major sporting events such as olimpic games, world skiing championships, world boxing championships, other sports that attract attention. They are not only on his own athletes, but also thousands of spectators or fans.

2. Sporting Tourism of the Practioners Sports events are for those who want to practice and practice themselves such as mountain climbing, horseback riding, fishing, and so forth.

The potential of sports tourism within tourism development efforts in Indonesia have multiple impacts for the development of regional tourism. This can be seen from the implementation of one sport tourism event in the province of West Sumatra is the Tour De Singkarak (TDS). The implementation of the first year of 2009, TDS followed by four districts / cities and in 2013 developed into 10 districts and 7 cities, held from 2 to 9 June 2013. The history of the beginning of the Tour De France in France and this event has been 100 years old. The Tour De France event, watched by 10-12 million viewers, was hosted in Italy's 6.8 million viewers, and was held at Sancos Tour Down with 750 thousand spectators. (Variety of Enchantment February 2013). The implementation of TDS 2013 is followed by 22 teams with team members from 26 teams consisting of 16 International Team and 6 National Team. The origin of the TDS Member 2013 includes 26 countries: Australia, Belgium, Brunei Darussalam, Canada, Chinese, Taipei, Eritrea, Germany, Hongkong, Iran, Japan, Indonesia, Ireland, Kazakhstan, Lithuania, 

University

Luxembourg, Malaysia, Netherlands, New Zealand, Philipines , Singapore, Spain, Thailand, United States of America, Uzbekistan and Vietnam. The media will cover TDS 70 printed and electronic media.

Television media includes Associated Press TV, RCTI, Kompas TV, TV3 Malaysia, Trans TV, SCTV Contributor and TV One. Media Partner TDS 2013 includes Eurosport, Metro TV, Jakarta Newspaper, Jakarta Globe, Sound Updates, Investor Daily, News one.Com, Press Photo, Male, Super Ball, Mens Health, Top Score, Kompas.com, Singgalang, Padang Pos. (Dit.Marketing Domestic 2013, Astuti 2015: 35)

Other sporting events are Bali Race and Rally 2015. This event was first introduced in 1981 and was held in 1986, 1998, 1990, 1993 and 1997. From 1997 to 2012, it was not held and started in 2013. The event was held to attract more sailing ships (Yatch) and international sailors to the homeland to visit the various islands and cultural diversity of the archipelago.

The immediate impact of these activities is expected to bring more than 500 tourists to Indonesia, especially to Bali. In addition, the event is to promote marine tourism and enhance the image of Indonesian tourism in the world, as well as strengthen bilateral relations between Indonesia and Australia. In this case the historic harbor in Australia, Freemantle will be associated with Bali in the activities of Wonderful Indonesia Freemantle to Bali Race and Rally 2015 (Travel Indonesia May 2015 in Astuti, 2015: 38).

Indonesia has held a Moto GP event in two consecutive years 1996 and 1997 at Sentul Bogor Circuit. As the world champion for the prestigious $500 \mathrm{cc}$ class in the 1996 racing season when it was Mick Doohan, while in the 1997 racing season as world champion was Tadayuki Okada. In the 1997 season at the Sentul Circuit when it was a legendary MotoGP rider. Valentino Rossi had won in the 125 cc class (Astuti, 2015: 39). Of the three events mentioned above, of course have a positive impact for the local government and surrounding communities. Not only the organizing committee who feel the positive impact in terms of economy, but also the owners of the hotel around which incidentally as a provider of lodging services for domestic and foreign tourists. From the food traders (both restaurants and street vendors), drinks, accessories, clothes, and souvenirs also feel the positive impact of the procurement of the race. The potential of sports tourism in Indonesia is actually quite large, basing on the geographical situation of Indonesia, it is not possible sport tourism such as rock climbing, rafting, hiking, diving and outbound can be used as a reference of domestic or foreign tourists to visit in some areas in Indonesia that provide sports like the. Therefore, it is necessary to develop the potential of sports tourism from the local community and the local tourism department to attract visitors to come and flock to enjoy the natural beauty of Indonesia and all its development.

Good marketing strategy and well-organized and clean management become the way to do for local stakeholders to promote sport tourism in their area. Following the development of the age and science of information technology is growing, then the relevant stakeholders can easily make recognition or promotion via the Internet or even through television programs that are currently being discussed hot "My Trip My Adventure".

For example, the sport tourism area in Gili Labak area on Madura Island is only known by the surrounding community, thanks to the visit of "My Trip My Adventure" team so that now make the potential of nature tourism and sport in Gili Labak become famous. Sport Diving is a major tourist destination.

For example again in the area magetan, magetan area is a mountainous area, there are many nice hills and fertile soil. the location of magetan district between two 
developing cities namely madiun and solo city, often madiun people if they want to go to solo through magetan city with the reason to pass the mountain, the weather is cool, not stuck, and near. Well local government and investors there are good at reading business opportunities that have high economic value. In the hills plaosan magetan many young people who hang out there, just sitting around enjoying the scenery or just take a picture of selfi, often as a stopover for tourists to rest. Finally, the local government must cooperate with the local community and the tourism office to create a conceptual tour, which combines nature and sports with the name "wista Mojo Semi". Mojosemi Tour presents the Out Bound rides with a variety of facilities and infrastructure for children and adults, food corner, rest corner, picking and planting fruit strowbery, provided also a place to take a picture with 3D concept, very nice to take pictures selfi and many the others. Under it Mojosemi in the Plaosan area as well and not far from the out bound mojosemi tour there is a cros motor track and almost every year held a cros motor competition. As a result, with the crowds of visitors who come, the surrounding communities feel the good impact, the fishermen in the local area many of the profession as a transportation service that leads visitors to the location, then opened a lot of vehicle custody, the establishment of new inns, food, and others that in fact all of it is strengthening the economy of the local community through sports tourism.

\section{CONCLUSION}

The challenges of the global economy have penetrated into various fields in this life. If the competitiveness of society in the face of the global economy is weak, then it is certain to be left behind. Indonesia with natural resources available need care and development in order to be maintained and profitable for the people of Indonesia itself. With such unique geographical conditions, Indonesia Human Resources is expected to be able to manage the natural resources optimally.

With the development of nature tourism in Indonesia as well as sports tourism, making Indonesia has its own charm for foreign tourists. With the development of sports tourism in Indonesia such as the procurement of international events (MotoGP Indonesia, Tour De Singkarak, and Bali Race 2015) as well as sports tours such as outbound, diving, hiking, rafting, and rock climbing, provide a direct impact for the people of Indonesia in general, especially local communities and local governments in economic terms.

With these sports tours, local people can provide things that are related to all the needs for tourists such as transportation or lodging service providers, food and beverage sellers, and various souvenir vendors that can improve their economy.

If sports tourism continues to be maintained and developed, as well as good management, it does not close the possibility of the number of tourists who come will also increase and the income of the local community will also be increased which will improve and strengthen the economy of the surrounding community.

\section{REFERENCES}

Astuti, T.M. (2015). Potensi Wisata Olahraga Dalam Meningkatkan Kunjungan Wisatawan. Jurnal Kepariwisataan Indonesia. Vol.10 No.1, pp.31-40.

Humaidi, Ismail. (2015). Peningkatan Perekonomian Masyarakat Melalui Industri Kecil. Skripsi Universitas Islam Negeri Sunan Kalijaga. Yogyakarta.

Satria, Dias. (2009). Strategi Pengembangan Ekowisata Berbasis Ekonomi Lokal Dalam Rangka Program Pengentasan Kemiskinan Di Wilayah Kabupaten Malang. Journal 
of Indonesian Applied Economics. Vol.3 No. 1, pp.37-47.

Undang-Undang No: 10 tahun (2009). Tentang Kepariwisataan.

Undang-Undang No: 3 tahun (2005). Tentang Sistem Keolahragaan Nasional 